\title{
The Competitive Anxiety (Cognitive, Somatic, Afective, and Motoric) among Martial Art Athletes
}

\author{
Donny Wira Yudha Kusuma ${ }^{1}$, Mugiyo Hartono ${ }^{2}$, Mohammad Annas ${ }^{3}$, Harry Pramono ${ }^{4}$, \\ Endang Sri Hanani ${ }^{5}$, Pradesta Ayu Krismonita ${ }^{6}$ \\ \{donnywirayudhakusuma@mail.unnes.ac.id ${ }^{1}$, hartonofik@ mail.unnes.ac.id ${ }^{2}$, syakhusti- \\ ni@mail.unnes.ac.id ${ }^{3}$ \}
}

Universitas Negeri Semarang, Semarang, Indonesia ${ }^{1,2,3,4,5,6}$

\begin{abstract}
The comparison of anxiety profiles on martial arts remains an interesting object to be examined. The present study is to compare the competitive anxiety characteristics between martial art athletes. Survey design was used in this study, this was to determined anxiety condition of Student Sports Training and Education Center (PPLOP) in Central Java Province. A total of 59 athletes from seven various of martial art of Central Java athletes (fencing, wrestling, karate, pencak silat, taekwondo and judo) composed the sample. The instrument used was the Sport Anxiety Scale (SAS). The result reported that Judo has the highest mean on cognitive anxiety (11.20) and motoric anxiety (34.20). Thus, pencak silat has the highest mean score on afective anxiety (11.40). Boxing has lowest mean score on cognitive anxiety (9.33), somatic anxiety (17.83), and motoric anxiety (28.83). One could observe based on the results found, that athletes on each martial art are constantly distinguished.
\end{abstract}

Keywords: competitive anxiety, martial art, central java.

\section{Introduction}

The interaction between technical, tactical, physical and mental is a factor that influences the athletes appearance [1-3]. The study in the sports psychology show that there are personality diversity between swimmers, wrestlers, basketball athletes, baseball athletes, and footballer [4]. Other study found on soccer, wrestling, gymnastics and karate shows that the personality characteristics of the athletes are different [5]. According to Williams \& Reilly [6] based on the results of the research on football there are some psychological characteristics such as high confidence, control of the level of arousal, focus on high tasks and the capacity to perform fully spirit that need to be known by young athletes. While sports psychology studies specifically on martial arts have been reviewed in previous studies [7,8], the advantages of martial training reviews [7,9], and reviews of psychological effect for mid age martial training [10]. Along with this, [11] found that karate athletes scored significantly higher on achievement, conscientiousness, visualization, intuition, goal setting, managing pressure, selfefficacy, fear of failure, flow, emotion, self-talk, self-awareness, ethics, empathy, relationship and impression management. Pencak silat athletes scored significantly higher on adaptability, stress management, power and aggressiveness. Taekwondo has highest average only on competitiveness variable. 
The literature review shows that the aspects psychology have differences in each individual in performance. Grossarth-Maticek et,al [12] reported psychological factors related to success in soccer and boxing athletes. Mahoney et al, [13] illustrated The ideal profile constructed by the sport psychologists generally paralleled the skill differences encountered, although the elite athletes did not report selected amplitudes in the profile. Furthermore, Bäckmand $\mathrm{H}$ et,al [14] found that athletes who had participated in power/combat sports and team sports were more extroverted, more satisfied with their lives than were the referents. It is concluded that former athletes differ from nonathletes in some personality characteristics and depression. Zinsser et,al [15] concluded that optimism is important for martial art athletes because it will have an impact on improving fighting power, concentration, and focus on attention.

The obvious factor that really affects the ability of athletes is psychological factors. One of the aspect is anxiety. Many studies examined the impress of anxiety in sport performance $[16,17,19]$. Usually, anxiety reported when performer were not confident in dealing with stress inducing competition situation [19] and and possibly affect various types of sports [20].

Anxiety usually occurs in athletes were called competitive anxiety. Competitive anxiety is a specific negative response in personal emotion to competitive stressor (Fletcher, et al, 2009). Research in the link of competitive anxiety and performance was based on the inverted$\mathrm{U}$ hypothesis. Basic opinion or hypothesis put curvilinear connectivity between performance and arousal $[1,22]$.

There are different point of views about anxiety; the state anxiety and trait anxiety were made by Spielberger [23,24], and the second is the somatic anxiety and cognitive anxiety conveyed by Martens, et al,[27]. Trait anxiety refers to anxiety in the aspect of personality. He said when anxious, athletes experienced the physiological changes associated with high stress, including rised heart rate and blood pressure, 'butterflies' in the stomach, faster breathing and flushed face. Anxiety increases heart rate and blood pressure. Increases metabolism and increased oxygen consumption. The dimensions of competitive anxiety tend influenced by sex, type of sport and level of ability. Concerning sex, female athletes are more prone to feel more anxious compared with male athletes [1].

The comparison of competitive anxiety profiles on martial arts remains an interesting object to be examined; but must take into account the methodological view and validity. Needs to be added to the number of athletes, not just to one group of athletes but in the sub-group who need limits in the study. In this context, the present study is to compare the competitive anxiety characteristics between Martial art athletes (Karate, Pencak Silat, Taekwondo, Wrestler, Boxing, Fencing and Judo), verify similarities and differences between groups.

\section{Methods}

Survey design was used in this study with ex post facto research design. This was to determined anxiety condition of Student Sports Training and Education Center (PPLOP) in Central Java Province. A total of 59 athletes (women, $n=32$ and men, $n=27$ ) from seven various of martial art provincial athletes of Central Java (fencing, wrestling, karate, pencak silat, taekwondo and judo) composed the sample. All individuals were informed about the objectives of the research and that data would only be used for research purposes and generally analyzed, and they signed a consent form to participate in this study. Samples obtained from 
athletes who are at the Central Training Center for Student Sport (PPLOP) of Central Java province.

The instrument used was the reviewed Indonesian version of the Sport Anxiety Scale (SAS) by Smith, et al, (1990). that containing 22 questions with 4 indicators; somatic (items: 1, 4, 9, 10, 12, 15, 20), cognitive (items: 3, 7, 12), motoric (items: 2, 5, 6, 13, 16, 17, 18, 19, 22), and afective (items: $8,11,14$ ). The final score from 22 to 88 for all score of SAS, with 22 indicating low anxiety and 88 indicating high anxiety. For each item, athletes indicated how they uniquely felt based on 4-point Likert scale, ranging from not at all (1) to very much (4). The data was taken during Nasional Competition of PPLOP or multi events competition, and spesific competition of sports. Test conducted \pm 30 minutes before the competition match begin.

For the analysis of the competitive anxiety between martial art athletes, the descriptive analysis was initially used (average and standard deviation) for the behavior of each variable to be studied. Later, after making sure the normality of data using Kolmogrov-Smirnov test. Multivariate Analysis of Variance (MANOVA), at the significance level of 0,05 was used in order to determine the differences between study groups.

\section{Results and discussions}

In this study, we examined comparisons were made between various martial arts sports in anxiety items (cognitive, somatic, afective and motoric) using Multivariate Analysis of Variance (MANOVA). Comparisons were made between indicators of competitive anxiety and between type of martial arts sports.

\subsection{Socio-demographic characteristics}

The socio-demographic sample is shown in Table 1, ie: the total number of samples of 59 athletes (female, $n=32$ and male, $n=27$ ) from seven (7) martial art provincial athletes of Central Java, 10 pencak silat athletes $(m=4, f=6), 5$ judo athletes $(m=2, f=3), 10$ wrestling athletes $(\mathrm{m}=7, \mathrm{f}=3), 6$ boxing $(\mathrm{m}=1, \mathrm{f}=5), 9$ karate $(\mathrm{m}=4, \mathrm{f}=5), 12$ taekwondo $(\mathrm{m}=6, \mathrm{f}=6)$, and 7 fencing athletes $(\mathrm{m}=3, \mathrm{f}=4)$. The mean of age for all samples were 16.2.

Table 1. General characteristics of the samples $(n=59)$

\begin{tabular}{|c|c|c|c|c|c|c|c|c|}
\hline $\begin{array}{c}\text { Characteris- } \\
\text { tics }\end{array}$ & $\begin{array}{c}\text { Pen- } \\
\text { cak } \\
\text { silat }\end{array}$ & $\begin{array}{l}\text { Ju- } \\
\text { do }\end{array}$ & $\begin{array}{l}\text { Wres- } \\
\text { tling }\end{array}$ & $\begin{array}{l}\text { Box- } \\
\text { ing }\end{array}$ & $\begin{array}{c}\text { Kara- } \\
\text { te }\end{array}$ & $\begin{array}{c}\text { Taekwond } \\
\text { o }\end{array}$ & $\begin{array}{l}\text { Fenc- } \\
\text { ing }\end{array}$ & $\begin{array}{l}\text { To- } \\
\text { tal }\end{array}$ \\
\hline n (Total) & 10 & 5 & 10 & 6 & 9 & 12 & 7 & 59 \\
\hline n (Male) & 4 & 2 & 7 & 1 & 4 & 6 & 3 & 27 \\
\hline n (Female & 6 & 3 & 3 & 5 & 5 & 6 & 4 & 32 \\
\hline Age (mean) & 17.3 & 16.4 & 16.1 & 15.8 & 15.4 & 16.6 & 16 & 16.2 \\
\hline
\end{tabular}

\subsection{Comparison of competitive anxiety among martial art athletes}

The result of comparison of groups showns in table 2., there are have differences among martial art sports on cognitive anxiety variable ( $\mathrm{sig} .=0.024<0.05$ ), and no defferences reported for afective anxiety, somatic anxiety and motoric anxiety (sig.=0.066;0.145;0.237>0.05). Judo has the highest mean on cognitive anxiety (11.20) and motoric anxiety (34.20). Thus, 
pencak silat has the highest mean score on afective anxiety (11.40). Boxing has lowest mean score among other types of sports on cognitive anxiety (9.33), somatic anxiety (17.83), and motoric anxiety (28.83).

Table 2. The study of mean defference among research groups in the competitive anxiety

\begin{tabular}{|c|c|c|c|c|c|c|c|c|c|c|c|c|c|c|c|c|c|}
\hline \multirow{2}{*}{\multicolumn{2}{|c|}{ Variable }} & \multicolumn{2}{|c|}{ Pencak Silat } & \multicolumn{2}{|c|}{ Judo } & \multicolumn{2}{|c|}{ Wrestling } & \multicolumn{2}{|c|}{ Boxing } & \multicolumn{2}{|c|}{ Karate } & \multicolumn{2}{|c|}{ Taekwondo } & \multirow{2}{*}{$\begin{array}{c}\text { Fencing } \\
\text { mean }\end{array}$} & \multirow{2}{*}{$\begin{array}{r}\mathbf{F} \\
\text { S.D }\end{array}$} & \multicolumn{2}{|c|}{ Sig. } \\
\hline & & mean & S.D & mean & S.D & mean & S.D & mean & S.D & mean & S.D & mean & S.D & & & & \\
\hline \multirow[t]{4}{*}{ Anxiety } & Cognitive & 10.20 & 1.476 & 11.20 & 1.095 & 9.60 & 3.026 & 9.33 & 2.066 & 10.33 & 2.000 & 9.92 & 0.900 & 9.71 & 2.138 & 0.596 & 0.024 \\
\hline & Afective & 11.40 & 1.265 & 10.80 & 1.095 & 9.50 & 2.877 & 10.83 & .983 & 10.67 & 1.658 & 10.58 & 1.832 & 9.43 & 2.225 & 1.272 & 0.066 \\
\hline & Somatic & 20.00 & 2.981 & 19.40 & 1.949 & 20.10 & 5.043 & 17.83 & 2.137 & 21.33 & 2.345 & 19.58 & 2.392 & 18.29 & 3.946 & 0.981 & 0.145 \\
\hline & Motoric & 31.20 & 4.077 & 34.20 & 1.095 & 30.10 & 8.595 & 28.83 & 3.920 & 32.33 & 4.359 & 30.58 & 4.963 & 32.43 & 3.309 & 0.735 & 0.237 \\
\hline
\end{tabular}

Then, Karate have top mean score on somatic anxiety (21.33). fencing has lowest score on afective anxiety (9.43). While for taekwondo and wrestling are in between other martial art sports, because the all score mean is among other martial arts sports. With the result if it is sorted from top to bottom, then the sport has the highest to lowest anxiety level in a row is judo, karate, pencak silat, taekwondo, fencing, wrestling, and boxing.

There are various factors that cause athletes to appear anxiety, especially feelings of anxiety, anxiety because of fear of failure in the match, fear of injury or injury to the opponent, and fear of not being able to compete properly is a separate burden and can be a stressor that can cause anxiety if the athlete cannot overcome it [27]. In line with Drost (2014) reported that the most dominant element causing anxiety is the cognitive element, namely negative worries and thoughts that the process and outcome of a match can threaten the athlete's position. Besides stress is cumulative then the occurrence of anxiety in athletes can also be caused by factors outside individual athletes such as pressure from the audience, family environment and the coach [28].

High anxiety getting flogged will cause an athlete to fail to show his appearance well. On the field athletes are reluctant to take risks to make certain movements. Even this anxiety will lead to feelings of trauma and even depression makes it less achievement. Psychological interventions that can be used to overcome this are counseling, relaxation and stress management [29]. A good psychological condition is really needed by an athlete, because by having a good psychological condition most likely an athlete will have psychological rigidity in every competition or championship. As an illustration, an athlete can be anxious when competing with a large audience. The audience's apparent effect on an athlete is generally in the form of a decline in mental state, so that it cannot perfectly display its best performance [30,31]

Kusuma \& Mulyono (2019) reported [11] that karate athletes significantly higher on achievement, conscientiousness, visualization, intuition, goal setting, managing pressure, selfefficacy, fear of failure, flow, emotion, self-talk, self-awareness, ethics, empathy, relationship and impression management. Pencaksilat athletes scored significantly higher on adaptability, stress management, power and aggressiveness. Taekwondo has highest average only on competitiveness variable. 


\section{Conclusion}

The objective of the present study was to compare competitive anxiety between martial art athletes in karate, pencaksilat, taekwondo, fencing, boxing, wrestling, and judo, also presented results that contrasted with findings of studies previously performed. Then, sorted from top to bottom, the sport has the highest to lowest anxiety level in a row is judo, karate, pencak silat, taekwondo, fencing, wrestling, and boxing. However, it became clear that athletes are significantly distinguished in most psychological variables studied. One could observe based on the results found, that athletes on each martial art are constantly distinguished. This verification indicates consistence of the data collected and points to a possible generalization of differences between individuals from both groups; fact that deserves further investigations.

\section{References}

[1] Jones G, Hanton S, Connaughton D. What is this thing called mental toughness? An investigation of elite sport performers. In: Journal of Applied Sport Psychology. 2002. p. 205-18.

[2] Bompa TO, Gregory Haff H. Periodization: Theory and Methodology of Training. 5th ed. United States of America: Human Kinetics; 2009.

[3] Abbott A, Button C, Pepping G, Collins D. Unnatural selection: Talent identification and development in sport. Nonlinear Dynamics Psychol Life Sci. 2005;9(1):61-88.

[4] Allen MS, Greenlees I, Jones M. Personality in sport: A comprehensive review. International Review of Sport and Exercise Psychology. 2013.

[5] Singer RN, Hausenblas H a, Janelle C. Handbook of Sport Psychology. Handbook of Sport Psychology. 2000. 13-19 p.

[6] Williams AM, Reilly T. Talent identification and development in soccer. J Sports Sci. 2000;

[7] Fuller JR. Martial arts and psychological health. Br J Med Psychol. 1988;

[8] Woodward TW. A review of the effects of martial arts practice on health. Wisconsin Medical Journal. 2009.

[9] Tsang TWM, Kohn M, Chow CM, Singh MF. Health benefits of Kung Fu: A systematic review. Journal of Sports Sciences. 2008.

[10] Douris P, Douris C, Balder N, Lacasse M, Rand A, Tarapore F, et al. Martial Art Training and Cognitive Performance in Middle-Aged Adults. J Hum Kinet. 2015;

[11] Kusuma DWY, Mulyono A. Comparison of Athletes Personality between Martial Art Sports in Central Java. Res Anal. 2019;05(03):2357-61.

[12] Grossarth-Maticek R, Eysenck HJ, Rieder H, Rakic L. Psychological factors as determinants of success in football and boxing: The effects of behaviour therapy. Special Issue: Sport and leisure: Therapeutic aspects. 1990.

[13] Mahoney MJ, Gabriel TJ, Perkins TS. Psychological Skills and Exceptional Athletic Performance. Sport Psychol. 2016;

[14] Bäckmand H, Kaprio J, Kujala U, Sarna S. Personality and mood of former elite male athletes - A descriptive study. Int J Sports Med. 2001;

[15] Zinsser N, Bunker L, Williams JM. Cognitive techniques for building confidence and enhancing performance. Appl Sport Psychol Pers growth to peak Perform. 2006;

[16] Kusuma DWY, Bin W. Effect of Yoga Program on Mental Health: Competitive Anxiety in Semarang Badminton Athletes. J Kesehat Masy. 2017;13(1):121-30.

[17] Ford J, Ildefonso K, Jones M, Arvinen-Barrow M. Sport-related anxiety: current insights. Open Access J Sport Med. 2017;

[19] Englert C, Bertrams A. Anxiety, ego depletion, and sports performance. J Sport Exerc Psychol. 2012 ;

[20] Arent SM, Landers DM. Arousal, anxiety, and performance: A reexamination of the inverted-U hypothesis. Res Q Exerc Sport. 2003; 
[21] Brooks AW. Get excited: Reappraising pre-performance anxiety as excitement. J Exp Psychol Gen. 2014;

[22] Fletcher JR, Esau SP, MacIntosh BR. Economy of running: Beyond the measurement of oxygen uptake. J Appl Physiol. 2009;107(6):1918-22.

[23] Jarvis M. Sport psychology: Routledge Modular Psychology. 2005. 146 p.

[24] Spielberger CD. CURRENT TRENDS IN THEORY AND RESEARCH ON ANXIETY. In: Anxiety. 1972.

[25] Spielberger CD. Theory and Research on Anxiety. In: Anxiety and Behavior. 1966.

[27] Martens R, Burton D, Vealey RS, Bump LA, Smith DE. Development and validation of the Competitive State Anxiety Inventory-2. In. In: Competitive Anxiety in Sport (edited by R Martens, RS Vealey and D Burton). 1990.

[28] Smith RE, Smoll FL, Schutz RW. Measurement and correlates of sport-specific cognitive and somatic trait anxiety: The sport anxiety scale. Anxiety Res. 1990;

[29] Hardy L, Beattie S, Woodman T. Anxiety-induced performance catastrophes: Investigating effort required as an asymmetry factor. Br J Psychol. 2007;

[30] Drost J, van der Does W, van Hemert AM, Penninx BWJH, Spinhoven P. Repetitive negative thinking as a transdiagnostic factor in depression and anxiety: A conceptual replication. Behav Res Ther. 2014;

[31] Schwab Reese LM, Pittsinger R, Yang J. Effectiveness of psychological intervention following sport injury. Journal of Sport and Health Science. 2012.

[32] Sanghvi T, Jimerson A, Hajeebhoy N, Zewale M, Nguyen GH uon. And young child feeding practices in different country settings. Food Nutr Bull. 2013;

[33] Epting LK, Riggs KN, Knowles JD, Hanky JJ. Cheers vs. Jeers: Effects of audience feedback on individual athletic performance. N Am J Psychol. 2011; 